\title{
CHARACTERISTICS OF FARMING AND TREKKING TOUR PACKAGES IN NORTH BALI
}

\author{
Putu Eka Wirawan. Sekolah Tinggi Pariwisata Bali International \\ wirawanputu@gmail.com
}

\begin{abstract}
Buleleng regency in North Bali is one of the districts that tourism in the area has not developed optimally. Topography of southern part in Buleleng regency in the form of plateau has the potential to develop rural tourism. Munduk village in Banjar subdistrict is one of the village that have potential to be developed as rural tourism because it is located away from the bustle of the city and the societal conditions tends to traditional. Munduk village started to move forward to welcome the arrival of tourism.

This study uses the concept of the cycle of attraction and stage the level of relationship between tourists and local people or local society. Bali Lofty Tours and Travel is a company which concerned about the education of tourism in Bali, as evidenced by the provision of education programs or education tour. Trekking activities'in Munduk village involve the local people who tend to remain in the stage of euphoria. People welcome the presence of tourists. In addition, Munduk village has arrived in stages between involvement and development. The purpose of this study was to provide knowledge and a general description of trekking in the Munduk village and its relation to rural tourism. Data were collected using observational and in-depth interviews methods, also by using sampling purposes method, the data analytic method using qualitative descriptive.

By writing this paper expected that the promotion is not only done at schools outside of Bali, but also schools in Bali and by increasing activity in farming package in Munduk village and the government should assist in the promotion, improve road access and also supply parking area in Munduk village.
\end{abstract}

Keywords: Tour Package, Tourist Characteristic, Local People

\section{INTRODUCTION}

\subsection{Background}

During this time, many opinions states that: Balinese tourism concentrated in Badung, Gianyar and Denpasar. The other districts are often forgotten and causing the imbalance. Buleleng regency in North Bali is one of the districts that tourism in the area has not developed optimally. Tourism in Buleleng focused on two areas, they are: Kalibukbuk tourism area better known as Lovina area, and tourism area of Batu Ampar. Both area is identical to marine tourism, because of the attractions are provided for the tourists. Lovina area which located along the sea coast of Bali has been known as home to the flock of dolphins, whilst, Batu 
Ampar has been famous for its underwater natural beauty. Centralization of tourism in these two points makes the lack of government attention to the other locations that also has the potential to be developed as an alternative tourism. Rural tourism one example of alternative tourism can be packed in such a way to fill special niches during postfordisme as now. According to the theory postfordisme, where special niches arise from fragmented market, this niche can be exploited in such a way to develop the economy of that area. Topography of southern part in Buleleng regency in the form of plateau has the potential to develop rural tourism. Munduk village in Banjar subdistrict is one of the village that have potential to be developed as rural tourism because it is located away from the bustle of the city and the societal conditions tends to traditional. Munduk village started to move forward to welcome the arrival of tourism. Some tourism activity began to appear. This should be followed up in order to make Munduk Village develops with significant planning.

\subsection{Study Problems}

According to the background above, the problems that arise are:

1. How the characteristics of marketing package and types of activities of Education Tour Farming and Trekking in North Bali?

2. How the existence of the location and the society based on the theory of The Tourism Life Cycle and Host Irritation?

\subsection{Benefits of the Study}

Academic benefits of this study to the reader, whether it is students or common people, can provide knowledge and general description about Bali Lofty Tour and Adventure. Simultaneously, provide general decription of trekking in Munduk village and its relation with rural tourism.

\section{LITERATURE}

\subsection{Review of Literature}

There are two results of final reports related to support this study. The first final report was written by Abdi Sucipta (2010) entitled "Strategi Pengembangan Ekowisata Desa Blimbing Kecamatan Pupuan, Kabupaten Tabanan, Tahun 2014". This study have similarities in development of trekking, cycling, camping and agrotouris as a natural tourist attraction by utilizing natural resources and local resources, and also the location of the study was the same, are on the object have not developed. Furthermore, in International Annual digital journal on study in Convervation and Cultural Heritage by Robert and Eryurt (2013) entitled "Culture Routes in Turkey". There are similarities in the focus of this study is equally examined the potential in development of trekking route in supporting tourism activity.

\subsection{Concept}

This study uses the concept about the cycle of tourist attraction known as The Tourist Area Life Cycle proposed by Butler (1980) and concept about stage level of relationship between tourists and local people proposed by Beeton (2005). 


\section{STUDY METHODS}

\subsection{Study Sites}

This study was conducted in two places with a study focus on a trekking tour. The first tourism destination is Bali Strawberry that can be reached through the land by private transport or public transport for one and a half hours from Denpasar or approximately $80 \mathrm{~km}$ towards the north Denpasar to Singaraja. The second location which was a focus study is the Banjar Bulakan, Munduk Village, Banjar subdistrict, Buleleng Regency. This location was chosen as location of the study because of Banjar Bulakan in Munduk Village still green and their people are still traditional.

\subsection{Scope of Discussion}

To limit this study and clarify the problems that will be discussed, hence the scope of discussion needed in this study, includes:

a. Trekking activity in Munduk village as the attraction of rural tourism.

b. Relation between local people and tourist in trekking activity also the existence of Munduk village as tourist attraction.

\subsection{Types and Data Source}

This study uses two types of data: qualitative data of Strauss and Korbin's opinion (2003). Meanwhile data source of this study is the primary data source proposed by Umar (2003). For technique of collecting the data, this study uses three techniques, they are: observation and interview techniques by Moleong (2004), also library study technique by Namawi (1995). Mechanical determination of informant in this study use purposive sampling technique by Mukhtar (2013). Meanwhile, for data analysis in this study use descriptive qualitative data analysis by Moleong (2004)

\section{FINDING AND RESULT}

\subsection{Characteristics of Education Tour Package: Farming and Trekking to} North Bali

Farming and Trekking to North Bali tour packages were one day tour package. Bali Lofty Tours and Travel is a company which concerned about the education of tourism in Bali, as evidenced by the provision of education programs or education tour by providing an affordable price which is specifically made to serve students. Farming and Trekking to North Bali tour packages are under tour types of farming education, where students as the target, they can get closer about the plantation and in touch with nature.

Tourist who follows this first tour will be invited to Bali Strawberry in Banjar Taman Tanda, Baturiti-Bedugul, Tabanan regency. Here the tourists will invite to learn how to treat the strawberry, and interacting with the strawberry farmers. After that they will be heading to Munduk Village, Banjar Bulakan, Buleleng Regency. Here they will be guided to the rice terrace trip that was quite far behind the hill. On that way, they are able to interact with farmers and coffee plantation owners. This will provide the tourist experience and new knowledge and local people will have a positive impact on the existence of the tour package. 


\subsection{Marketing of Education Tour package: Farming and Trekking to North Bali}

Bali Lofty Tour and Adventure markets their tour packages via internet and sales call. Party of Bali Lofty Tour and Adventure opened the widest cooperation network both domestic and abroad. If there are others that require travel tour packages of Bali Lofty Tour and Adventure, the travel can buy tour packages which are then the profits will be shared equally. Moreover, the Bali Lofty Tour and Adventure do the marketing to the schools and universities outside of Bali.

Bali Lofty Tour and Adventure marketing their tour packages with promotions such as lower prices thus, it affordable for students and the benefits to be gained by the students are gaining experience and new knowledge about farming and trekking in Bali.

4.3 The Existence of Location and Society Based on the Theory of The Tourist Area Life Cycle and Host Irritation

a. The Existence of Location and Society Based on the Theory of The Tourist Area Life Cycle

Figure 1. The Tourist Area Life Cycle

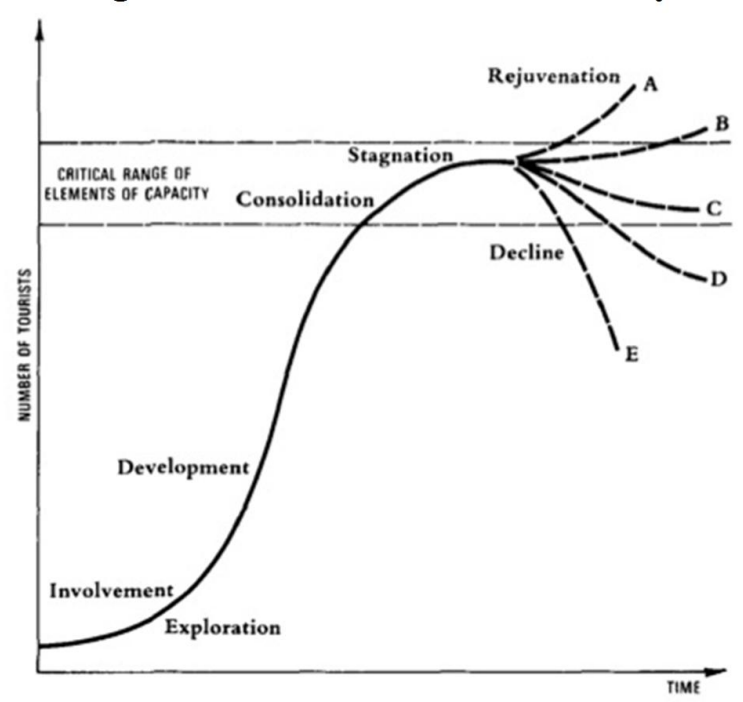

Source: Butler, 1980

As a tourist attraction, Munduk Village in Banjar subdistrict, Buleleng Regency is a village located in the middle stages of involvement. According to the theory of the Tourist Area Life Cycle (Butler, 1980) stated:

“...Involvment - local initiatives provide facilities and some advertising ensues. Large number of visitors, a tourist season and public sector involvement follows".

Munduk Village as well. Trekking activity in Munduk Village is at a stage of involvement towards development. The local people have initiated to provide facilities and there are already ads about Munduk Village on several internet sites. The number of visitors also increased. In addition, there is also the influence of 
the public sector and seasonal tourist arrivals to the society. Proved by increasing number of shops that closed during the low season. In theory, the activity of trekking Munduk Village has passed the exploratory phase, but has not fully arrived at the development phase, since not much information can be obtained by the media on trekking tours in the Munduk village. However, there have been some changes to the industry around tourist destinations, including the development of agro-tourism and development of tourism support facilities such as: restaurant and cottages.

\section{b. The Existence of Society based on the theory of Host Irritation}

\section{Table 1. Doxey's Irridex Model of Host Irritation}

\begin{tabular}{|c|c|c|}
\hline & Social Relationship & Power Relationship \\
\hline Euphoria & $\begin{array}{l}\text { Visitors and investors } \\
\text { welcome }\end{array}$ & $\begin{array}{l}\text { Few planning or formalized } \\
\text { control. Greater potential } \\
\text { for influence to be exerted } \\
\text { by locals (not often taken) }\end{array}$ \\
\hline Apathy & $\begin{array}{l}\text { Visitors are taken for } \\
\text { granted. } \\
\text { More formal relationship } \\
\text { between host and guest. }\end{array}$ & $\begin{array}{l}\text { Marketing is the prime } \\
\text { focus of plans } \\
\text { Tourism industry lobby } \\
\text { grows in power }\end{array}$ \\
\hline Annoyance & $\begin{array}{l}\text { Resident misgiving about } \\
\text { tourism } \\
\text { Range of saturation points } \\
\text { approached }\end{array}$ & $\begin{array}{l}\text { Planners attempt to control } \\
\text { by increasing } \\
\text { Infrastructure rather than } \\
\text { limiting growth. } \\
\text { Local protest groups } \\
\text { develop to challenge. } \\
\text { Institutionalized tourism } \\
\text { power }\end{array}$ \\
\hline Antagonism & $\begin{array}{l}\text { Irritations } \\
\text { expressed } \\
\text { Residents perceive tourist } \\
\text { as the cause of the } \\
\text { problems }\end{array}$ & $\begin{array}{l}\text { Remedial planning fighting } \\
\text { against pressures of } \\
\text { increased promotion to } \\
\text { offset declining reputation } \\
\text { of destination. } \\
\text { Power struggle between } \\
\text { interest groups }\end{array}$ \\
\hline
\end{tabular}

Source: Beeton, 2005 
Doxey Irridex as can be seen in the table showing the four stages of the host irritation. Row of euphoria shows social relationships between local people in Munduk village. Local people not only accepted investors and foreign tourists, but also studyers and domestic tourists. People are very enthusiastic about the parties that they think will develop tourism in Munduk village.

Based on the power relationship, formal sector in Munduk village not much developed. In addition, Munduk Village also evolved by on few planning. The potential that exists in Munduk village was developed by the local people leading to the increase the number of tourists is slowly but surely. If Munduk Village continue to develop as a location for trekking activities, it is not impossible if in a few years, people will enter the stage of apathy phase, where the host-guest relationship there will be some distance because of the formalities. This is what should be anticipated by the government.

\section{CONCLUSION}

Type of activity in Education Tour package: Farming and Trekking to North Bali is gardening the strawberry in Bedugul and Trekking in Munduk village. Trekking activity in Munduk Village involving local people as provider for supporting the facilities such as: food and coffee shops and also guide. Marketing Education Tour packages: Farming and Trekking to North Bali done through a system of sales calls by open its network to outside of Bali, held a sale via the Internet and in cooperation with other travel. Trekking activities in Munduk village involve local people who are likely still in the stage of euphoria. People welcome the presence of tourists. In addition, Munduk village has arrived in stages between involvement and development because investors have started to develop Munduk Village, but the information in the media still inadequate to say the development stage.

The suggestion for manager and local government for the promotion is not only done at schools outside of Bali, but also schools in Bali and by increasing activity in farming package in Munduk village and the government should assist in the promotion, improve road access and also supply parking area in Munduk village.

\section{REFERENCES}

Beeton, Sue. (2005) . Society Development Through Tourism. Australia : Csiro Publishing.

Boniface, Brian and Cooper, Chris. (1987). Worldwide Destination : The Geography of Travel and Tourism. Oxford : Elsevier ButterworthHeinemann.

Butler, R.W. (1980). The Concept of A Tourism Area Cycle of Evolution : Implications For Management of Resources. Canadian Geographer 24, 5-12.

Doxey, G.V. (1975). A Causation Theory of Visitor-Resident Irritants: Methodology and Study Inferences. In Travel and Toursim Study 
Association Sixth Annual Conference Proceedings. Pp. 195-98. (TTRA, San Diego).

Mokhtar. (2013). Metode Praktis Penelitian Deskritif Kualitatif. Jakarta : REFRENSI ( GP Press Group )

Moleong, L.J. (2004). Metode Penelitian Kualitatif. Bandung : PT. Remaja Rodakarya.

Namawi, H. Hadiri. (1995). Metode Penelitian Bidang Sosial. Yogyakarta: Gajahmada Universty Press.

Strauss, Anselm dan Juliet Corbin, (2003). Dasar-dasar Penelitian Kualitatif. Yogyakarta: Pustaka

Umar, Hussein. (2003). Metode Riset Komunikasi Organisasi Jakarta. Jakarta: PT Gramedia Pustaka Utama 